\title{
Chinese Entrepreneurship: Institutions, Ecosystems and Growth Limits
}

\author{
Wei Zhao", Frank La Pira \\ Ecole Supérieure de Commerce Saint-Etienne,Address: 51-53, cours Fauriel BP 29, 42009 Saint-Etienne, France \\ *Corresponding Author: wei_zhao@esc-saint-etienne.fr
}

Copyright (C) 2013 Horizon Research Publishing All rights reserved.

\begin{abstract}
This article gives an entrepreneurial perspective on the competitiveness of China's industries in the economic globalization, especially since the 2008 financial crisis. It explains above all how China gained the traditional competitiveness (from comparative advantage to competitive advantage) through rapid technological learning of its entrepreneurial firms. Behind these firms, it was the Chinese State as an ensemble of economic actors who had strong incentives to grow the whole industrial production aggressively. During the global financial crisis and recession, China took the lead in the turnaround. Now, it is expected to take the lead in the next cycle of economic growth. However, the external foundation underpinning China's fast growth is in serious disarray. The shifting globalized economy is challenging the Chinese entrepreneurs and its growth model. The paper gives some clues on what China should do to be competitive in the future. The empirical part of the research is based on Chinese macroeconomic data and in-depth firm level interviews in China during a long period of time. ${ }^{1}$
\end{abstract}

\footnotetext{
1 The macroeconomic data were collected from the Chinese official statistical yearbooks of various years, including China Statistical Yearbook (2002-2012), China Industry Economy Statistical Yearbook (2005-2012), China Trade and External Economic Statistical Yearbook (2005-2011), China Science \& Technology Statistical Yearbook (2000-2012), Statistics Yearbook on Science \& Technology Activities of Industrial Enterprises (2007-2012). All these yearbooks are compiled by China's National Bureau of Statistics (with Ministry of Science \& Technology or National Development \& Reform Commission for specialized statistics) and published by the Beijing-based China Statistics Press. The main fieldwork in China was carried out between March of 2007 and April of 2009 through the research program "Innovation Potential of Chinese Industries", financed by the Hong Kong -based French Research Center on China (CEFC) and in cooperation with the Research Institute of Guangdong Development (Sun Yat-sen University in China). Empirical information is based on visits and investigations of a number of government bodies and firms mainly in Guangdong Province, which is often called the "world factory" due to its lion share of $25.1 \%$ (2011) in China's foreign trade value. At each visit, in-depth interviews of 1-2 hours were undertaken first with local economic and technological officials (mainly from Economy \& Trade Commission or Science \& Technology Department at city or township level) and relevant policy documents were collected. Government officials from the following administrations were interviewed: Guangdong Textile and Apparel Industry Association, Zhaoqing City Government (Guangdong), Jiangmen City Government (Guangdong), Shuikou Municipal Government (Guangdong), Xiqiao Municipal Government (Guangdong), Humen Municipal Government (Guangdong), Dachong Municipal Government (Guangdong), and Wuhan High-Tech District Administration Committee (Hubei). Most of our firm visits were recommended, arranged and accompanied by local governments, with their preferences of selecting the large sized, relatively well performed and technologically sophisticated local firms and entrepreneurial activities. At each firm visit, in-depth interviews lasting 1-2 hours with senior managers or company owners were also undertaken,
}

Keywords Entrepreneurship, China, Economic Policy, Global Value Chain, Innovation, Business Ecosystem, Technological learning

\section{Introduction}

Competitiveness is a comparative concept of the ability and performance of a firm, sub-sector or country to sell and supply goods and/or services in a given market (Berger, S., 2006). It captures the awareness of both the limitations and challenges posed by global competition, at a time when effective government action is forced by budgetary constraints and the private sector faces significant barriers to competing in domestic and international markets. Paul Krugman (1994) once notes that countries don't compete, firms compete. He argues if national competitiveness has any substantive meaning, it must reside in the factors about a nation that facilitate productivity. But in practice, the concept is still a mixture of situations at both national level and firm level.

Economic globalization triggers questions on what China's competitiveness is and how it will compete. As China has emerged as a major economic force, there is a clear distinction between the 'optimistic' and 'pessimistic' camps. Some believe that China is emulating Japan, Korea and the Asian 'tiger' economies and creating internationally competitive, innovative, high-tech firms like Sony or Hitachi, thus transforming itself into a modern industrialized country. Some others say that Chinese economy already reaches its

followed by factory or site visit. Firms studied include: Fenghua High-Tech Corporation (Zhaoqing), Huaiji Auto Accessories Company (Huaiji), Zhaoqing Auto Parts \& Accessories Company (Huaiji), Dachangiiang Motorcycle Group (Jiangmen), Shuopu Motorcycle Technology Company (Jiangmen), Hedy Group (Guangzhou), Delica Plumbing Equipment Company (Shuikou), Shuikou Technological Innovation Center (Shuikou), Yishion Group (Humen), Humen Textile Innovation Center (Humen), Fumin Fashion City Company (Humen), Xiaiqo Textile Innovation Center (Xiqiao), Dachong Furniture Technology Center (Dachong), Zhengda Pharmaceutical Company (Wuhan), Balance Pharmaceutical Company (Wuhan), Mike Bio-Pharmaceutical Company (Xiamen), North-East Pharmaceutical Company (Changchun), Geely Group (Ningbo), Delphi Shanghai Ltd. (Shanghai), Desano Bio-Pharmaceutical Company (Shanghai), and Shanghai-Volkswagen Company (Shanghai). 
limit and will soon collapse. For example, after two years of nearly $12 \%$ GDP growth in 2006-07, Chinese growth slowed to $9 \%$ in 2008 . In late 2008 , with the world financial crisis, there was economic slowdown in China, closures of factories and 20 million workers unemployed. But from 2009 to 2010, China's GDP growth rate slightly jumped from $9.2 \%$ to $10.4 \%$. However, pessimistic voice rises again when China's GDP growth rate fell from $9.2 \%$ in 2011 to $7.8 \%$ in 2012 .

This article takes neither an optimistic nor a pessimistic perspective on Chinese economy. It tries to present a realistic picture of China by evaluating its firms' behavior and the overall economic functioning. It proceeds in four stages. Section 2 will summarize how Chinese firms and entrepreneurs have gained competitiveness by now. Through identifying their main paths of technological learning, it is concluded that Chinese firms and entrepreneurs have potential innovation capacity but are facing fundamental constraints. Section 3 analyzes the institutional foundations of entrepreneurship and enterprise creation in China. The root of these institutional arrangements is firms' socio-economic categorization based on ownership or property rights. It is important to understand these "administrative heritages" of firms, because they shape both the current configuration of assets and capabilities, and the cognitive orientations of entrepreneurs toward future growth, including international growth. Section 4 extends the analysis from the creation of entrepreneurs' ecosystems to the functioning of whole Chinese economy. Chinese economic growth is due to its unique socialist Keynesian model of macro financial circulation. Section 5 describes how China is now promoting the competitiveness of its firms. But all the strategies are facing severe challenges from the globalized economy. Section 6 will conclude the paradox of China's macroeconomic performance and firm competitiveness.

\section{Entrepreneurship through Learning: the Chinese Way}

Traditional competitiveness of nations and firms refers to comparative advantage based on resource endowments, as well as competitive advantage based on cost-leading or differentiation strategies of firms, sometimes based on industrial clustering environment created by States. More advanced competitiveness refers to higher level advantage of firms based on innovation, especially when firms learn to master the global value chain. The strategy of innovation management consists of designing, developing and implementing a recurring basis, with new products and services to be valued in different markets according to firm's own technologies and core competencies. Recently, firms and governments of advanced economies count on developing competences in new fields of corporate social responsibilities, sustainable development, and corporate governance performance. More and more, competitiveness is the combination of advantages created by firms and governments in generating new rules of game, and is far beyond the traditional competition in market place.

How well has China competed until now? China has been able to export a number of sophisticated high-end products based on its cheap labor and it has gained the competitiveness in the traditional sense. From 1993 to 2004, the rate of productivity growth of enterprises has exceeded $15 \%$, with an average growth rate of TFP (total factor productivity) of $4.7 \%$ in the period 2001-07. Productivity growth fell dramatically to an average of $2.8 \%$, however, during the global financial crisis of 2008-2010, and improved only marginally afterwards. The profit rate of firms has increased by $6.7 \%$ in 2000 to $23 \%$ in 2006 . The Chinese industrial sector, the largest part of the economy, reported average return on equity (ROE) of 13.8 percent in the period 2001 to 2011. The good performance of Chinese companies has shown a trend that they were entering the door of innovation. By 2006, it seemed that the Chinese industry has developed some capacity to innovate in terms of $R \& D$ investments and creation of industrial technology centers by multinationals in China (OECD, 2007). From 1995 to 2005, China had 19\% growth in R\&D budget on reaching U.S. \$ 30 billion per year. In 2006, in terms of R \& $\mathrm{D}$ expenditure and number of personnel in $\mathrm{R} \& \mathrm{D}$, China was the second country in the world. Since 2007, China's R\&D expense ratio to GDP steadily increased from $1.49 \%$, to $1.54 \%$ (2008), to $1.70 \%$ (2009), to $1.76 \%$ (2010), to $1.84 \%$ (2011), to $1.97 \%$ (2012). The increasing activities in technology development are certainly more visible in Shanghai or Beijing. Some Chinese companies have shown the "Success Stories". The group Huawei spent 9\% of its turnover, or 5.9 billion Yuan in R\&D, and even established an R\&D center in Silicon Valley. The Lenovo Group has also reached an R\&D expenditure of 2.8 billion Yuan. More and more companies in China incorporate higher added value functions and lower the cost of each function, including R \& D. Some authors have concluded directly that Chinese companies have developed a new model for breakthrough innovation, the so-called cost innovation (Williamson \& Zeng, 2007).

Schumpeter (1934) emphasizes the fundamental function of entrepreneur is innovation. The typical Schumpeterian entrepreneur is different from simple administrative officer or owner-capitalist of means of production. Entrepreneur is the first person introducing a new thing to an economic system. Entrepreneur is a true adventurer who does not hesitate to think for innovation and must overcome the resistance opposed to anything new that might challenge the conformism. According to Schumpeter, entrepreneurial activities of innovation are the very engine of economic growth. But Chinese firms' gaining of advanced competitiveness is in fact a process of rapid catching-up. The concept of "catching up" implies that the more an economy is far from the maximum level of development, more technological progress is rapid, because the costs of adaptation and diffusion of technology are known to be lower than the costs of innovation and invention that 
advances the technological frontier (Benoît, F. ed., 2004). While entrepreneurship in China is present, the Schumpeterian innovation of creative destruction is absent. Chinese entrepreneurship has not been dependent on indigenous inventive capacity, but on the ability to "borrow" technology from the world's "technological shelf", i.e., on the basis of learning (Amsden, A., 1989). These foreign designs, products or processes are not path breaking, but are novel in the Chinese context. Learning in entrepreneurship involves borrowing, adapting and improving upon foreign designs. At cognitive level, learning of productive knowledge and innovation based on articulation of new knowledge are of the same logic. High level learning can lead to formulate competitive advantage based on innovation. This means that all learning activities have an internal tendency and potential to become innovation. For catching up economy, the more learning is approaching innovation, the more important the role of system support provided by the State.

Since the beginning of 1980s, China has been carrying out a massive movement of foreign technology acquisition throughout its industrial firms. Over time of the past 25 years, Chinese entrepreneurs developed two patterns of technological learning. Simply put it, one is based on traditional arrangement of technology transfer, which is the model adopted by most State firms, represented by automobile firms under the form of joint ventures and large State-owned electronic firms in the 1980s and 1990s. This pattern of technology transfer emphasizes the thorough assimilation of technological and the underlying scientific knowledge. The key process is "reverse engineering" followed by continuous quality improvement, product development from imitation to innovation, and economic transition from import substitution to export orientation. Japan, and South Korea to some degree, are successful examples of this model. The South Korean experience shows the switch from basic productive capability to a more complex technological capability is linked, but not exclusively, to the introduction of $\mathrm{R} \& \mathrm{D}$, to some organisational sophistication process, and to the integration of technology and markets in the strategy of the firm (Kim, 2000). Chinese government supported fully this pattern of technology transfer, interfered in the transfer process within firms directly or indirectly, and even forced the transfer behaviour sometimes. Correspondingly, Chinese government elaborated series of industrial and technological policies in service of this model, built up institutional infrastructures to promote the imitation to innovation process, reinforced Chinese basic research and industry linkages in purpose of drawing indigenous technological capabilities from technology transfer. The current national innovation system modulated by government is for this way of technological learning at firm level.

But there was another way of learning in China, practiced mostly in the non-state firms (many of them are in electronics industry) emerging after Chinese economic reform and open-door policy. Chinese entrepreneurs learnt their technologies from serving their clients and competing in the market. This model of learning that the most dynamic Chinese entrepreneurs are experiencing can trace their origins to East Asian catching-up model (see for example the work of Hobday, 1997). In fact, learning in the emerging Chinese enterprises has not created a new paradigm for the learning literature. On the contrary, the learning experience of the Chinese enterprises is an ordinary process, a follower of the Southeast Asian model. Even firms advancing more rapidly toward an innovation frontier are in this pragmatic, down-to-earth catching-up model, upgrading cumulatively productive and control knowledge. ${ }^{2}$ These firms introduce new models as long as their foreign clients provide them new blueprints. Firms that seem to enter in a transitional stage in upgrading from a basic productive learning to more sophisticated technology learning maintain the same diversified types of contacts with their clients, aggregating more sources of knowledge and trying to keep a multiplicity of external sources. These firms follow a mixed pattern of interactive learning, maintaining a variety of sources of technology, keeping a large portfolio of clients and products, accepting to be both OEM providers for some products and an autonomous brand for others, depending on the market.

During the last 25 years, the progressively fierce competition in Chinese market made the non-state emerging firms flourish over the State-owned enterprises. Thus the practical learning pattern prevailed over the formal transfer pattern in industry. But these emerging firms obtained little support or backup from the arrangements of Chinese innovation systems due to their institutional status. Even some local governments begun to construct supporting arrangements for these firms by promoting local industrial clusters, such as in Guangdong Province (Zhao, Wei, Arvanitis, R. and La Pira, F., 2011), the State innovation policy is still biased to serve the state firms. There is a deep institutional and organizational gap between the dominant practice of technology development in mainstream firms with strong catch-up characteristics and the legitimate system of innovation set up by government with target of indigenous innovation. Except the few Chinese super star companies which are innovative and accidentally fell into the government expectations, because they practiced interactive learning at the same time benefiting from innovation system due to their special status (such as Lenovo, Haier, Huawei, which begun to have international expansion), most of Chinese emerging firms are continuing to reinforce their capability of production and investment, instead of

\footnotetext{
2 This observation is mainly based on detailed case studies of 19 automobile and electronic firms in China, carried out during 1998 and 2006. Most of the joint-venture companies in Chinese automobile industry during the period were included and most of the studied electronic firms were found in Guangdong Province, China's then most important province of electronic products manufacturing and exporting. Full case evidence and analysis can be found in Zhao, Wei (2000 and 2013), and Arvanitis, Rigas, Wei Zhao, Haixiong Qiu and Jian-niu Xu (2006).
} 
upgrading to innovation, even some of them are beginning to expand these production capabilities abroad. Chinese enterprises are still concentrated on production capabilities and difficult to enter find themselves in other higher value-added functions, such as product design, logistics and transportation, material integration, marketing, design, and selling, etc. Even some Chinese enterprises begun to invest in $\mathrm{R} \& \mathrm{D}$, their new higher value-added functions are found mostly in domestic value chains in China. Many case studies prove that Chinese enterprises have little capability of innovation in the global value chains.

China's technological learning at the firm level brings nothing new to the existing models of catch-up firms in South Korea and other newly industrialized economies (Hobday, M., 1995; Kim, L., 1997; Amsden, A., 2001). Though these paths of technological learning led South Korean firms from imitation to innovation, for Chinese firms they only bring them potential capability of innovation. The growth regime of Chinese catch-up has been based on a combination of particular economic and social factors by now, such as growing need for consumption in domestic and foreign market, large scale investment in infrastructure for 20 years, a pool of cheap labor market without limit, in the absence of social protection and safety at work, an increased supply of skilled labor (during the last 10 years university graduates has increased significantly), and free from intellectual property protection, etc. But to turn this potential into real innovation, Chinese firms also encounter three main constraints: the institution for entrepreneurship (the mechanism problem of origination of new firms), its position in global value chain (the linkage problem with technology suppliers and good buyers), and sustaining market demand for more sophisticated products (the linkage problem with customers and consumption). The following sections check these three aspects in more detail.

\section{Institutional origins of the Chinese Entrepreneurship}

It is often neglected that Schumpeterian entrepreneurship involves more actors than just one single entrepreneur, so the context of entrepreneurship must be taken into account. This context includes other groups and individuals whose cooperation is needed for a successful business performance. Since 30 years, thousands of new enterprises were created in China. During 1998 and 2007, the number of above-scale industrial firms in China increased from 165 thousand to 302 thousand, with an increase by 5.8 times of manufacturing sales. There is no shortage of capitalist entrepreneurs and bureaucrats in China who also have a strong ambition to create a powerful 'national team' of firms which will be genuine global competitors. However, to understand why China has plenty of entrepreneurial activities while is still lack of innovation, it is necessary to look into the histories of entrepreneurship, and find the reasons within the Chinese institutional contexts. It is the institutional condition of creating new firms in China impedes the entrepreneurship to embody innovation from the beginning. In fact, the entrepreneurship in China has a background of dual economic emergence of the private sector and the renascent state sector, and co-evolution between new market players and former planning players. For over 20 years China has developed a very special socialist market economy, characterized by the dominance of government control, but with emergence of a private sector composed by Chinese local firms, Chinese overseas firms, and foreign firms. In parallel to the emerging private sector, China has also sustained and even reinforced its state sector, transforming itself from the old planned style to a new Keynesian system. Private enterprises are permitted to compete and operate in a free market environment, but the State grasps most of the benefits and redistribute to state-owned sectors.

\subsection{Renascent Entrepreneurship within State Sector}

Many wrongly believe that after the Soviet-style planned economy, reform since 30 years is leading China towards a capitalist market economy, in which private individuals and corporations own the means of production and, motivated by the desire for profit, compete in free markets under conditions of limited restraint by government. Many forget that China's fundamental economic institutions are ruled by socialist principles, deeply rooted in its political system. State sectors include SOE which is the core part. SOE are diversified firms under government control established by and around administrative bureaus during the 1980s. With the gradual opening of China in 1978, China's political authorities fostered connections between Chinese SOE subsequently leading to the creation of these business groups. The motivation for promoting such a development was influenced by the success of the Japanese Kereitsu or the Korean Chabeol. In 1995, the official numbers given was 20, 000 business groups in the country when it was also reported that they accounted for approximately one quarter of the total state-owned assets. In 1997, the State Council selected industries while incorporating small and underperforming state companies at the same time. Along with making China the "world factory" in the 1990s, resources, especially financial resources, were drawn back to the State sectors. Today, the share of SOE in business is estimated between $20 \%$ and $50 \%$; some of them are large enough such as Sinopec, State Grid, and China National Petroleum. Some of them are in the process of internationalization. At first there were only reductions in the planned sector and business changes, and there was no emergence. But gradually the State sector has learned to react to the pressure from private sector. China was eventually able to develop a new State sector that renews their activities by adopting new technologies and management systems, with funding from the profits channeled through the Sate-controlled financial institutions (banks, stock market, insurance companies, investment funds, or direct payments to local governments, particularly through their tax offices, etc.). The emerged 
State owned firms dominate the most important infrastructure sectors, such as telecommunications, petroleum, chemicals, even in automobiles and some electronics. It should be noted that the state sector also includes other organizations supporting the SOE: public health institutions, education, science and technology, finance, labor, etc. A recent example is Commercial Aircraft Corporation of China (CACC), a state-owned enterprise from China created in May 2008 by merging the commercial aircraft operations of two other existing state-owned enterprises, AVIC 1 and AVIC 2. The Chinese government has publicly stated its goal to make China a competitor in the global jumbo jet market by 2020. CACC's predecessor, AVIC 1, has already announced that it will be launching the maiden flight of ARJ21, a 70-100 seat passenger aircraft sometime during the year of 2009.

The firms created or renewed in the course of this State sector reemergence are mostly orthodox firms in the eyes of government and their growth is due mainly to subsidization from government. In China, there is a bias in favor of large State-owned enterprises in the design of policy instruments for innovation. This bias appears to influence the choice of policy instruments. For instance, programs for private-public partnerships for innovation, which have emerged in OECD countries as instruments to foster long-term industry-science linkages, have found their place in China to promote $\mathrm{SOE}$ and universities cooperation. In fact, Chinese policy mixes are characterized by the strong legacy of the planned economy, as the programs - literally "plans" in Chinese - are the main instruments for addressing policy priorities. The operation of national innovation system is very centralized, and the relation between State and SOEs are much closed. Chinese central government has purposefully followed the catch-up trajectory of Japan and South Korea, constructing national system specifically in service of state-owned enterprises. These firms continue to obtain State's support and take use easily resources in the national system of innovation.

Many big Chinese firms grew up in following this pattern, which reminds us always of the story of South Korea. In the South Korea case, a high rate of investment was maintained largely through the channeling of large amounts of subsidized credit to industrial enterprises controlled by the Chaebol (large, family-run conglomerates), although state enterprises played an important leading role in certain sectors (steel and petrochemicals, for example). Indeed, the high leveraging of investments was a central structural feature of the South Korean development model. But technological catch-up and international competitiveness require more than high rates of investment. The allocation of subsidies has rendered the government not merely a banker, but an entrepreneur, using the subsidy to decide what, when, and how much to produce. This State-entrepreneurship involved a combination of import-substitution and export-promotion. Cheap credit and access to protected domestic markets were provided to the favored Chaebol enterprises in exchange for achievement of export targets. If an enterprise failed to meet state export targets, the subsidies would be scaled back accordingly. Using these methods, the South Korean government was able to promote the development of internationally competitive production in a succession of new industries- textiles, shipbuilding, steel, automobiles, and consumer electronics. These industries successfully assimilated technologies obtained through the importation, and licensing agreements with foreign (mainly Japanese) corporations. Foreign direct investment also played an important, though subsidiary, role, mostly in the form of joint ventures. Such ventures were particularly important in electronics. More broadly, Korea's heavy industrial program was spearheaded by the large Korean Chaebols, all of which had close ties with the Japanese conglomerates (or large firms) through joint ventures upon whom they were largely reliant for technology transfers. The South Korean government's strong and sophisticated external negotiating stance, and its efforts to arrange the importation of management and engineering consultants (again mainly from Japan), were crucial factors in the country's acquisition of the foreign technologies, expertise, and capital needed for industrialization" (Amsden, A., 1989). This pattern of entrepreneurship is less similar to that of Japanese firms. Comparing to South Korea, Japanese State-firm structure adopted flat organizational form, with less degree of hierarchy between the higher level of government and lower level of firms. Japanese firms emphasized on experience accumulation and continuous progress in quality. Japanese firms had a unique intrinsic learning pattern which integrated closely design, production, marketing and R\&D to invent new production methods, such as JIT and Lean Production. Chinese big State firms intended to take the route of Japanese firms, but in a much less successful degree. Their efforts in international technology transfer are exactly in the same way as Korean firms, but also in a much less successful degree. Nevertheless, they get much stronger support from Chinese government than their South Korean and Japanese counterparts.

\subsection{Grass Roots Entrepreneurship}

But originally there was one kind of entrepreneurship in China: the private sector, or non-State sector, since private sector did not exist before, it has itself emerged as an island in the sea, which is sometimes described as bamboo capitalism (Economist, 2011). This pattern of entrepreneurship includes firms under different forms: red-hat enterprise, FDI from HK, TW and Macau, the late-comers business, etc. The private firms originated from the better exploitation of the residual resources in State sector. These resources were circulated outside the State sector system. The strength of these companies is very uncertain. They need to live and survive to create a clean living space, a specific knowledge, a learning exercise for both organizational and technological aspects, which can make them stronger. All other phenomena are logical consequences that flow from this first and only 
entrepreneurship in China. These new enterprises took the share of manufacturing in the global value chains, in exploiting the abundant and low-cost labor resources in China. Most of them exported to foreign markets and earned foreign exchange. Most of them were also in nature local FDI. In fact, the FDI occupied more than $40 \%$ of Chinese GDP, and FDI firms occupied $55.48 \%$ of national import and export, $87 \%$ of Chinese high-tech exports, and $90 \%$ of Chinese high-end automobile export. From the late 1990s, there begun to have more and more real Chinese private firms participating in global value chains. This export-oriented non-State sector constituted the main growth engine of Chinese economy during the last 25 years.

These Chinese entrepreneurs do not depend on support from China's national innovation system constructed by government. The entrepreneurs may be called "grassroots", because in their creation and growth process they get little attention and support from government. They are almost outside the sight of government. Their emergence is due to the combination of Chinese comparative advantageous domestic endowments, such as cheap labour, huge internal market space, abundant natural resources (Lin, J. Y., 2012), and the globalization of value chain and the recent formulation of international innovation system. The learning pattern of this entrepreneurship consists of a double process: one is taking part of the global value chain of industrial production; the other is taking use of Chinese comparative advantages in industrial production. The double process is nothing mysterious than just a normal industrialization process.

The disruption between 1980s and the before is the worldwide separation of functions of a value chain of production. Industrial production includes a series of functions from design of product to selling to client, sometimes until service after sales. Some steps imply production or transformation of manufactured goods; other steps consist of providing services or information. Nowadays, these functions are subcontracted one after another by the big brands to low-cost producers. Along this process, ownership linkages are replaced by the contractual relations between independent firms. These firms may be located in different places in the planet but are linked around a value chain (Berger, S., 2006). From 1990s, most of functions of production and components have been moved to China. The movement is not at firm level, but at industrial level, meaning all industries move their production and components sections to China. The globalization of value chain didn't industrialize some specific firms in China, but the whole country and its whole industries. This delocalisation of industries to China gave a golden opportunity to whichever Chinese firms, but specifically small and medium sized non-State firms, to absorb and develop production capacity. Learning started from production and component functions, but later some firms extended to distribution, product design, even marketing and after-sales service. It is a typical routine of Southeast Asian firms from OEM to ODM to OBM.
On the other side, grassroots Chinese entrepreneurship also benefited from the boom of huge domestic market. By leveraging technologies that they get from foreign clients to the domestic market, these Chinese firms begun to master all the functions in the value chain, from product development, through production, to marketing. They set up big vertical integrated organization to coordinate their activities, just as big firms for mass production in US in the $19^{\text {th }}$ century. The fast growth begins with cost advantages that large scale and broad scope provide in relatively technologically advanced and capital-intensive industries in China. It continues with heavy investments in manufacturing, marketing, and distribution. Also geographic expansion and moves into related product markets both lead to economies of scale, and economies of scope in Chinese market. These firms, when big enough, will also try to take use of the former reserve of scientific and technological competence, leaked out by former science and technology system in China, to industrialize the design and technology to mass production. But this linkage is always difficult to be inserted into formal plan of the State.

Thus most firms in this pattern of entrepreneurship, even those active in R\&D now, have both limited capabilities and a low propensity to innovate. The private sectors include only business firms, with little support from other sectors. Key factors include an emphasis on quantity rather than quality, which is a legacy of their entrepreneurship routine, the availability of cheap but insufficiently skilled labour, the lack of managerial know-how, a mode of governance that does not encourage managers to take the risk of innovating, the persistence of a government support system that tends to crowd out rather that encourage emerging private business investment in risky projects, and a financial system that is not supportive to them. In fact, many of the grassroots firms' innovation depends upon the various forms of public support granted by the different levels of government to tenants of science and technology parks. But the recent period has seen the clusters of small firms in some regions, notably Zhejiang, Jiangsu and Guangdong provinces.

\subsection{Boundary and Brokerage Entrepreneurship}

The institutional aspect of Chinese firms has been widely explored by Chinese scholars (Yasheng Huang, Xielin Liu, Justin Yifu Lin, etc.). This dual emergence of private enterprises (national IDE) and the renewed State sector creates a bias of access to certain strategic resources (technological, human, financial and even organizational) for entrepreneurship. The type of ownership (property rights) of an entrepreneurial course will determine its possibilities to get the support from outside the firm (education institutions, university research, public technology centers, banks loans, information sharing, etc.). Grass root entrepreneurs encounter major obstacles to the development of innovation (funding, control of strategic products, inability to recruit top level personnel, impossibility to get support in technical activity when it is not part of public companies or public or 
quasi-public bodies), even from the very start-up phase. Most grass root entrepreneurs have to find cooperation with state sectors, and enter into partnership with the State, in order to gain the needed resources. The solution is often to mix the private entrepreneurship with that in State sector and find a new institutional arrangement (red-hat of firm, subcontracting from SOE, fake joint-venture with SOE, subordinating to a non-profit public organization, etc.).

All these ways can be called institutional entrepreneurship in China. Most firms in this pattern have a hybrid institutional form of ownership from the beginning. They are often semi-public and semi-private firms, or the collective firms with vague ownership classification, or the mixture of State-assets and private investments. The State-owned aspects of firms permit them to have very specific insertion within the national innovation system and create a firm-specific context different from that of industrialization pattern. But their private or non-state aspects make firms adopt industrialization-type learning pattern. The uniqueness of this pattern is that entrepreneurs should have institutional access to resources provided by national policy and innovation system, benefit the equivalent regulation environment as the SOEs; at the same time, their firms' operation adopts totally the model of grassroots firms (mass production, cheap labour force exploitation, assimilating technologies from foreign clients, competing by price advantage and quantity, etc.). Moreover, entrepreneurship of this pattern skilfully combines the strong points from both State and market, brokering between State-controlled resources and market power. For example, a firm of this pattern can well integrate its $R \& D$ projects into national planning and get governmental subsidies, even direct investment in development; at the same time, it may use its huge production capacity to push its foreign clients to give more technologies, or to acquire foreign surplus production capacity and move it back to China. Entrepreneurs take advantage of the former immobilized technological reserves in planned innovation system and new technological knowledge of foreign clients and partners (Lu, Q., 1997). They in fact create an economic and technological convention between different systems, and their success depends on the brokerage capability of entrepreneurs.

Some of Chinese firms that have already acquired global visibility and market presence, even in high-technology sectors, such as Huawei, Haier, TCL and Lenovo, are typical cases of this pattern of entrepreneurship. Most R\&D-intensive Chinese firms usually emerged from the public research sector. This is the case for three leading Chinese producers of personal computers: the predecessor of Lenovo, Legend, was nurtured in the Institute of Computing Technology of the Chinese Academy of Sciences; Founder Electronics was a spin-off from Beijing University; and Tsinghua Tongfang originated from Tsinghua University. Some of these large successful firms are now investing abroad in R\&D. The small and less famous firms of brokerage pattern, such as Jinling Corporation, Fenghua Hi-Tech Company, Huaiji car parts firms and Dachangjiang
Motorcycle Group, adopted in fact very similar routine of giant successful Chinese firms. The disappearance of one side of system may destroy the firm, such as the case of Fenghua High-Tech Corporation. But it should not be forgotten that the joint-ventures in China, especially the joint-ventures between SOEs and MNCs are also following this process of entrepreneurship, even under a more structured organization and with less brokerage effects. These joint-ventures may follow more the pattern of State sector entrepreneurship if Chinese government imposes more control and the foreign investors have less confidence (the cases of JVs in automobile industry), or may follow the pattern of grassroots entrepreneurship, if the Chinese partner is a private entrepreneur and the foreign partner is well recognized, and its market power is protected by Chinese government (the case of Wahaha-Danone dispute). In any case, finding the appropriate institutional arrangement is the key element if the joint-venture wants to have successful growth in the domestic or export markets. But normally Sino-foreign joint-ventures are less successful cases of institutional entrepreneurship comparing to typical Chinese super star firms.

Since 30 years, the double emergence of State entrepreneurship (State-own firm reform, attracting foreign direct investment, export-led strategy) and private entrepreneurship (informal privatization of state-assets, township and village enterprises, and private firms) continuously created a variety of business firms in China, though the life-cycle of each specific firm was often short. Curiously, such intensive entrepreneurial activities didn't lead the whole economy to evolve from imitation to innovation, just as Japanese and Korean economies did. The reason is that most of entrepreneurs' resources and creation are contributed to Chinese unique institutional contexts to make the so-called institutional innovation. For entrepreneurs, firm is a cognitive focusing device or dominant logic device for collective action. The institutional identity of the firm serves to give a social and legal basis for the coordination, production and collaboration of resources. Institutional arrangement of ownership rights is needed to establish to control resources, and a generalized labor contract to coordinate resources. But in China, this institutional arrangement of ownership will subsequently determine more or less the firm's internal relationships and activities (organizational form, quality management, human development efforts, and compensation systems) and specific external linkages with suppliers, customers, and knowledge institutions. Thus it becomes the close focus and dominant logic of entrepreneurs in China. The innovation requires collaboration with outside and other organization, and focus on market, not institution itself. Nevertheless this Schumpeterian innovation lies outside the focal scope of Chinese entrepreneurship.

\section{Macroeconomic circular of Chinese Entrepreneurship}


Firm's production activities establish the linkage between investment and consumption. As a firm is created, it will enter into various interactions with other institutions and organizations (public authorities, universities, labor market, foreign buyers, laboratories, technical research centers, suppliers, financial institutions, users, consumers, clients, consultancies, investors, competitors, partners, etc.). It will also get involved into a chain of activities (undertaken by the firm or joint activities it carries out with other actors, e.g., searching government support to export to foreign markets, which is in fact a joint activity of firm and government, sometimes with banks). These activities, for theoretical purpose, can be roughly clustered in three categories: financing, producing and consuming. Financing activity often implies investment, such as $\mathrm{R} \& \mathrm{D}$, new product development, the decision to purchase and finance equipment, removal of plants, etc. Producing activity includes purchase, supply and logistics, equipment maintenance and operation, manufacture of components, quality control, and delivery of product, etc. They are mainly internal activities of a firm, but often contain its suppliers, connected companies, cooperative, sub-contractors, and specialized suppliers, often located in the same area. Consuming activity includes marketing, selling, services, distribution and logistics, market research, product design, product usage, in relations with users, clients, consumer, and market data, etc. Firm is embedded in all these activities. We may define all these business activities and interactions among actors beyond the frontier of a firm as a business ecosystem. An entrepreneur's ecosystem is, throughout time, a number of economic activities carried out in relation with a series of actors around a project of industrial production of an existing firm or an entrepreneur. As a concrete environment, ecosystem can generate opportunities that can be then exploited by the entrepreneurs.

\subsection{Dynamic Ecosystems of Chinese Entrepreneurship}

The exploitation opportunities provided by business ecosystems are the dynamic sources of Chinese entrepreneurship. In Chinese environment, new firms are created, often as result of investment. Entrepreneur and the new firm's linkages with other actors are almost predetermined by the institutional foundation of the firm ownership from its day of birth. For example, a private entrepreneur knows more or less how it will get labor, what forms of its network of suppliers will be, what its relations with banks will be, with whom it is able to cooperate with other firms in the industry, etc., before the firm is created legally. These institutionally determined linkage possibilities will specify more or less the ways the entrepreneur undertakes different activities. Thus entrepreneurs and firms in China are extended to different types of business ecosystems, once they get involved in activities regarding investment of production and consumption of products. Chinese firms are not only different in internal capability, but also in terms of their linkages as producers with financing and consumption opportunities, provided by their specific ecosystems.

Entrepreneurship within State sector mainly forms an investment-led ecosystem. The system is like a 'producer' chains leading to demands of the market (both consumers and corporate customers). For State-owned firms, the weight of business is located upstream and all activities, from manufacturing to marketing, are then guided by the possibilities of gaining investment. These firms are often legacies of former planning system in China, but under new form. Chinese governments often play the role of corporations, bankers and universities, and are the most powerful and biggest investors in the economy. The investment in State-owned firms is for investment itself, because new investment attracts more investment. In 2008, the State-owned enterprises (excluding the financial institutions) owned net assets of up to 17 trillion Yuan, and were almost all good-quality assets. The producing activities are normally in the upstream and monopoly sectors, such as infrastructures (telecommunications, transportation, etc.) or raw materials (petroleum, chemistry, etc.), equipped with advanced machinery and well-organized, well-paid employees. Huge fixed assets attract more investors (foreign and Chinese). When State makes investment in these firms, it includes also many programs of technology development, specifies formal links with universities and partnerships with banks. At firm level inside, the size is very important, and investor relations are fundamental. At government level, there is often strong involvement to implement industrial policy. In this kind of business ecosystem, entrepreneurs don't worry too much about the market, since customers or markets are already there. The consumption of their outputs is relatively stable and strong, often with the intervention of state or government (e.g., in pharmaceutical sectors, the State buys). Their market is domestic. The main customers of the State-owned firms are in fact other types of firms (private, foreign, and mixed ownership firms, etc.) as well as employees from other sectors (increasing population of migrating peasant workers, for example). The strategic positioning of these firms brings them revenues from other firms comfortably. Implementation of national strategies for employment, social stability, attracting foreign investment gives a lot of opportunities of growth for State-owned forms. A typical case, the State-owned Fenghua High-Tech Corporation, was ever the most innovative Chinese high-technology producer in semi-conductor. The firm had strong production capacity with low cost, and gained an important foreign client. After losing its foreign client, it turned to State for more investment to survive. Under the direction of the State, many banks gave loans, and the firm also had privilege to be listed on stock market.

As for most private entrepreneurs and their small and medium-sized firms, they often find themselves in a client-led ecosystem. The basis of this ecosystem is the interaction between producer and customer, often abroad. The dynamics does not rely on the firms themselves but on the relationship between the foreign client and the local firm. 
Typical firms are often the suppliers specialized in OEM mode, with their foreign clients who are themselves producers in foreign markets. Their relationship is that of outsourcing production for a foreign client, or assembly products according to foreign specifications, sometimes under the arrangement of compensatory trade (the same type as the Maquiladoras in Mexico). Foreign client is also supplier of technology to Chinese firm which is user of that technology. Foreign companies as clients are forcing Chinese manufacturers to improve product quality and processes to meet their increasing demands, so they dominate the relationship. At the same time, foreign companies provide technical assistance to Chinese firms, who do not know the market of Western consumers, but only their clients (Western firms). Consequently, few firms are able to monitor changes of habit and needs of users, and to take these changes into account in the design and operation of their products. Some products exported from China are placed in very demanding foreign markets, but these products are sold by multinationals. This has greatly reduced the chances of learning from markets. In fact, to the Chinese producer, the foreign client has become the barrier to its market access. But the producing activities are well developed on specific request of client. It is characterized by lower prices by a desire to improve and move up in the market, the use of a pool of unlimited labor supply from countryside, but a very high turnover rate that is bad to production quality. To be attractive to foreign firms, local governments often intervene to regulate the problems of manpower (security, control of unions, lower wages, job maintenance, etc.) to make firms flexible and efficient, and cost of production remain low enough. The investment for launching such production is very low, and local governments provide funds, helping also entrepreneurs to develop contacts with foreign clients. Sometimes, local governments act as intermediaries to make liaison with universities, technology centers, etc. Examples of industrial clusters in Guangdong Province, such as Shuikou, Dachong, and Nanhai, are all towns in specialized products manufacturing.

Different from normal private entrepreneurs, institutional entrepreneurship and the corresponding firms (Chinese red-hat firms, wholly foreign owned subsidiaries, powerful private entrepreneurs, etc.) often evolve their business into a real market-led business ecosystem. Here the opportunity is mainly Chinese domestic mass market and composed of non-demanding consumers. The chain of production is guided by the final consumer. The firms have the ability to adapt to conditions of sale. Firm's producing activity, from product design to delivery, is then guided by the needs of customers. The biggest difference between the opportunities provided by this ecosystem and the client-led ecosystem is that it is not a client, who dominates the relation, but the producer develops and manages a network of distributors to sell the product directly to consumers, and firms directly receive the feedbacks of consumers. Downstream activities are important to firms: the challenge is to achieve control and anticipate consumer needs (definition of trademark, etc.). Many entrepreneurs started their business as traders. Then they became producers under OEM arrangement for foreign customers. But gradually, they focus on the Chinese market (the requirements are lower than those of foreign customers) to build marketing power. Yishion Group in Humen, one of the biggest Chinese apparel retailers (known as the Chinese Zara), was originally a clothing producer, and then it established and managed a national network of distributors, and outsourced the production to some local providers. Sales revenues come from domestic consumers, who are also workers in SOE and private firms. In Chinese markets, consumers are not so in demand of high-quality products. The low disposable income made consumers demand for conventional products at low prices. The example of foreign retailers such as Carrefour highlighted this characteristic. Carrefour has relied on low prices; its price is even lower than that of Chinese supermarkets. Carrefour is engaged in a price war with Chinese competitors. With this policy and despite the strict limitation imposed by the central government, Carrefour has expanded rapidly and has made considerable profits. Also, China's savings rates are at up to half of its gross domestic product and are much higher than in other countries. Workers save money and have low consumption propensity. If firms want to keep their production activities going on, they have to find ways to earn margin from the weak consumption. Their strategy is to expand production capacity to benefit from scale economy. The increasing ability production industry in China is based on the slow growth of domestic demand and high expectation of entrepreneurs to reach mass production. Entrepreneurs in this situation spend considerable resources to forge links with their environment, with research institutions, suppliers and customers. Many entrepreneurial firms originated from other ownership categories can be evolved in this kind of ecosystem. Jinling Washing Machine Company, a local State-owned company in Jiangmen, transformed itself into a scaled producer led by foreign client, then extended to a market-led ecosystem.

\subsection{Creation of Entrepreneurs' Long-Term Expectations}

But how the whole Chinese economy without Schumpeterian entrepreneurship and innovation achieves to gain consecutive growth? The answer is found in understanding the macro monetary circular overflowing its various ecosystems of entrepreneurial activities. China's whole process of economic functioning and monetary circular can be shown by the Figure 1 as below. 


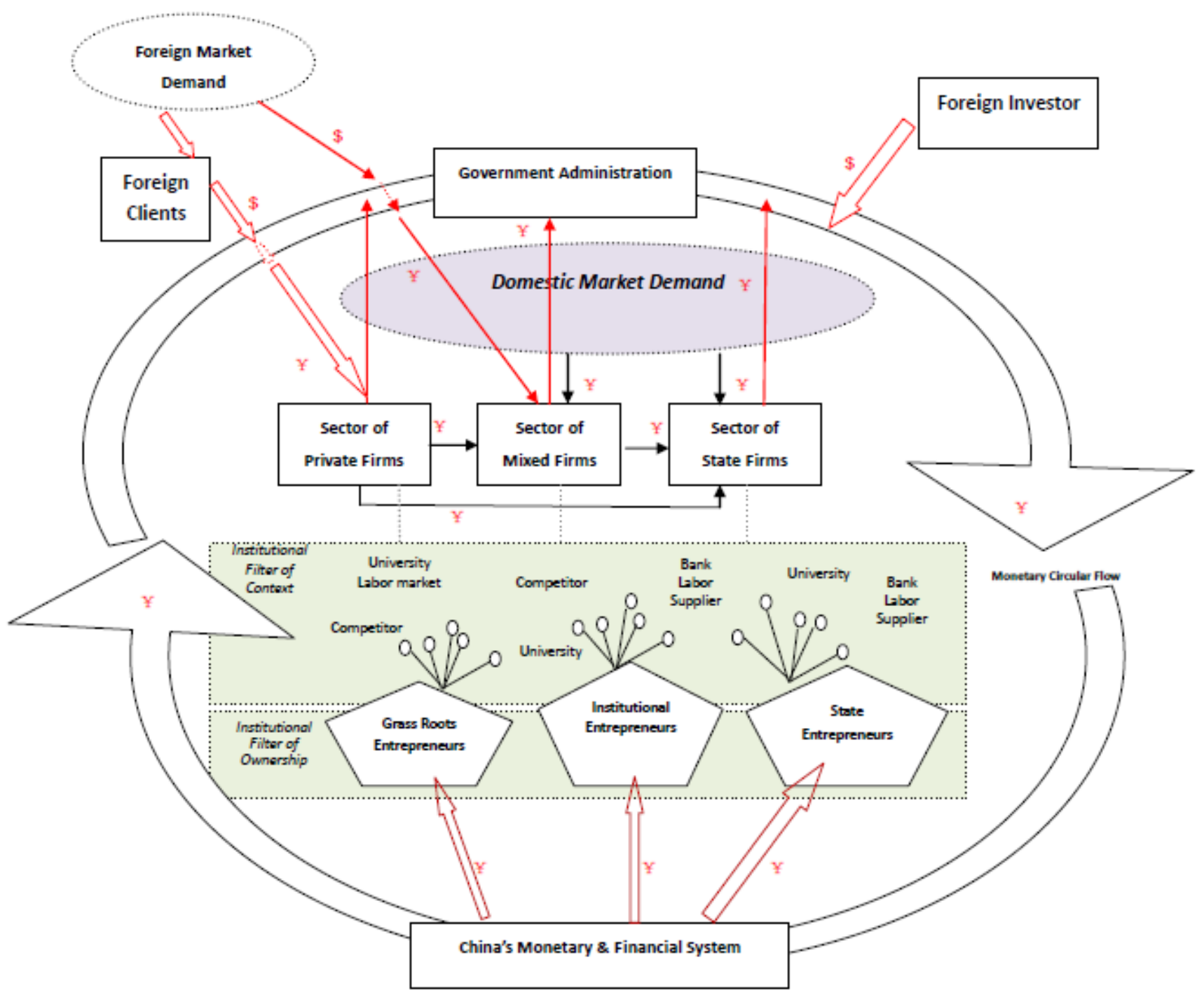

Figure 1. The Entrepreneurship-based Circular of Chinese Economy

Above all, China's unique monetary, banking and financial system is in fact a State-owned sector. Chinese Government has full control over money circulation process and uses the whole financial system (including its stock markets) as a huge financing machine for its economic expansion. In China, the use of interest rate as monetary policy tool is only recent. Government has managed the quantity of money through banks and financial institutions. The Chinese macro monetary and financial system has several characteristics. First, China's banks and financial institutions can effectively absorb the economy's monetary savings (see flows $¥ 1$ in Figure 1). China's total savings rate increased from $36 \%$ in 1996 to $51 \%$ in 2007 . Even if the interest rate is zero, China's savings would be still very high. This is because the whole financial sector is government-owned; households are not worried about the risk of bank failure and expect that the financial sector will always exist. And they don't know where to put their money, except saving in the banks. For a period of time, China's households even threw their money into the stock market in believing there is no risk of losing, because the stock market is a government-run. Household savings in China are about 20 per cent of gross domestic product, increasing during 11 years from $19 \%$ to $22 \%$. A high amount of savings comes from large companies in China. In fact, saving rate of government and business sectors increased during 11 years from $17 \%$ to $29 \%$, contributing $80 \%$ of the growth. These savings were mainly transformed to industrial investments in large firms through Chinese financial system. State-owned and large firms continued to expand their productive capacity. While small and medium-sized enterprises, which employ 80 per cent of workers, have minimal access to financial services because that sector is dominated by four large banks that primarily serve large companies. In effect, the skewed financial structure in China means that ordinary households and small and medium-sized companies have been subsidizing big corporations and the new rich class through the banking system with low interest rates. In addition to savings, the Government absorbs money through taxes and fees from firms and households (see flows $¥ 2$ in 
Figure 1). Since reform and opening of the economy, Chinese fiscal revenue is always at high speed of growth. In addition, the Chinese currency Yuan is not freely convertible. China's foreign exchange system absorbs most of the foreign exchange earnings of Chinese exports enterprises, and foreign currency brought by foreign investors (for direct investment or financial investment). Before this foreign currency flows into China's economy, they must be converted into Chinese currency to enter into the circulation in domestic market. This money, through the banks and the SAFE, becomes in fact Government's foreign exchange reserve. Besides, Chinese government set up a floating exchange rate system with reference to a basket of currencies. Since 2005, under international pressures, it has appreciated $20 \%$ of RMB exchange rate against the U.S. dollar. In fact, Chinese government is the biggest capitalist who produces and operates the economy's money, including RMB and foreign exchange (see flows $\$ 3$ and $¥ 3$ in Figure 1).

Under the Government's command, the key function of Chinese State-owned financial system is "investment transfusion", meaning channeling and allocating the savings and financial resources to investment projects in the real economy (see flows $¥ 4$ in Figure 1). The result of these continuous waves of investment is the 'piling up' of different types of productive ecosystems in China (Arvanitis, R., P. Miège, and Zhao, W., 2003). Entrepreneurial firms, especially new ventures, are receivers of these investments. But entrepreneurship in China has to go through the institutional filters which clarify the ownership of new firm. Ownership category then has big impact on the subsequent concrete situation of the firm. It determines with which institutions of knowledge it can establish linkages, as well as the nature of its interactions with financial institutions and users, clients, markets, suppliers, competitors, foreigners, etc. These linkages with others evolve into different ecosystems. Most banks in China are large banks and have no internal process adapted to give credits to small private entrepreneurs. They are used to finance the key projects within planned frameworks. "Investment transfusion" is biased to entrepreneurship within State-owned sector. Through the financial system, China uses private accumulations and foreign financial resources to feed its State-owned sector entrepreneurship. Tools of direct financing such as capital market are also for this purpose. It is not surprising to find that Chinese local governments and banks fund the sectors of steel, cement, road building, bridge building, real estates, etc. These infrastructure sectors accounted for about $30 \%$ of total economic output in 2007 and were dominated by State-owned firms, who had always the heritage of the classic "thirsty for investment" of socialist enterprises.

Chinese Government's investment push approach has created a high degree of aggregate effective demand at domestic level. According to Keynes (1936), effective demand is the anticipated demand by entrepreneurs. They calculate the output they must make in order to provide the optimum amount of goods and services required by economic agents. Before launching the production, which is expenditure of money, entrepreneurs have to anticipate the amount of revenues and expenses that may give them the profits they expect. In observing the preference for liquidity (currency) of people, Keynes concludes that if a market economy is left to itself, it cannot have effective demand. So society as a political unit, should replace the entrepreneurs in the decision to invest in the extent of their deficiency. By injecting investment continuously in circulation, Chinese government has created high expectations of revenue of all actors. Chinese banks gave loan schemes without taking into account of the risk. China's financial firms are almost all State-owned, with specific property rights and governance structures. In fact, the banks create credits according to Government's command. Once the investment is introduced in a fast-growing economy, all firms formulate high expected returns, so production continues to increase and the macro economy runs into an upward spiral. From 1990s, Chinese investment reached $50 \%$ of GDP. The investment rate has even exceeded those of Japan and South Korea for their take-off period. Investment in fixed assets was always double-digit more than sales of goods. Surplus of production capacity is a common phenomenon in Chinese manufacturing of end consumer products, which is an evidence of the high expectations of entrepreneurs. The high expectations come from several sources. One is no one thinks State banks can collapse, so debts for banks and firms are not frightening. The importance for Chinese government is to keep money circulating in the economy. Another reason is investment means that money will somehow be passed to someone's hands and the money will be spent somewhere. For individual entrepreneurs, the expectation is someone will buy the firm's products sooner or later. If the entrepreneur is in private sector, it will be a foreign client; if she is a State entrepreneur, she must take the action of investing, thus becomes others' customer; if she is an institutional entrepreneur, the customer can be a foreigner, a private entrepreneur, a State-owned firm, or even a State-owned organization in social sector (see flows $¥ 5$ in Figure 1). Many private firms in export sector turned to search domestic customers after 2008 crisis, but they had strong expectations of revenue. Thus, confidence beyond personal relations, with the party as quasi-clergy in a secularized, quasi-religious "developmentalist" State, turns out to be the clue for understanding the dynamism of recent Chinese growth (Manfred Nitsch and Frank Diebel, 2008).

On the other side, the real increase of consumption of Chinese goods met more or less the expectations of Chinese entrepreneurs, and made it possible that Chinese Government continue its investment push strategy (see flows $¥ 6$ in Figure 1). In fact, during the years, internal consumption has increased rapidly, though comparing with the even more rapid increase of supply and production capacity in China, it is often neglected. First, the growth of export demand constitutes an important monetary income source to Chinese economy. The average annual earnings of Chinese exports to the U.S. were in excess of $25 \%$ over the 2003-07 periods. China's export now has a world market 
share of $10 \%$, and it contributes $40 \%$ of GDP and $25 \%$ growth of GDP of the country. As China's export grows up, export income from foreign exchange are converted into Yuan. These revenues increase the incomes of workers in export sector, who constitute in fact a major part of the domestic market demand. This increasing demand then strengthens the expectations of earnings of firms in other sectors, such as township and village firms, foreign-invested firms, and State-owned firms. China's domestic market demand, after thirty years of growth, even with a low consumption propensity, has begun to boom. Domestic consumption occupies only $35 \%$ of its GDP, dropping from $45 \%$ in the $1980 \mathrm{~s}$, with an average increase rate of $1-2 \%$ per year recently. But China's financial system continuously allocates or leverages the financial resources to production investment, to the infrastructure sectors dominated by state-owned firms, and to other social sectors (which are state-owned also) such as education, health, and public security. These expenditures create many domestic demands, particularly for State-owned sectors and other non-state sectors. For example, China has an important export-oriented manufacturing sector, but $60 \%$ of the firms in this sector, mainly the grass roots entrepreneurs, buy their equipment and machines of production from Chinese markets. They create revenues to Chinese State-owned firms and other firms with mixed ownership.

In the end of 2008, Chinese government announced an economic stimulus package of 4 trillion Yuan investment in response to economic crisis. The quantity may be bigger, but the practice has been undertaken since 30 years. The so called Chinese active fiscal policy was already evident to the outside world during the Asian financial crisis in 1997 and the economic recession during 2000-2001. But taking the Chinese macroeconomic policy along, it is always a policy designed for the crisis period of market economy. Though its domestic consumption propensity is low, Chinese unique financial system makes strong investment inducements, even regardless of the marginal efficiency of capital. Compensated by the export demand growth, the effective demand of Chinese economy keeps high. Through its totally State-controlled financial system and foreign exchange regime, Chinese government jointly used monetary and fiscal policy tools to expand the money supply and investment scope. To some extent, China boosts its market economy in adopting the propositions advocated by Keynes for the period of economic and financial crisis. Whatever its political reason, Chinese government's short term macroeconomic measures with money created a strong linkage between the expectations of future revenue and the current investment decisions among the grass roots entrepreneurs, the State entrepreneurs, and the institutional entrepreneurs. Schumpeter (1934) stated that without the innovation activities of entrepreneurs, economy would become a stationary circular flow without growth dynamics, though he recognized the important role of bank credit to entrepreneurial innovation. Combining all the monetary flows into a unique circular arrangement to feed its non innovative but somehow dynamic entrepreneurship ecosystems, China in fact gives a very Keynesian solution to the Schumpeterian problem of economic development. In this sense, Chinese government is the ultimate and real entrepreneur of its economy.

\section{Growth Limits of Chinese Entrepreneurship}

From 1998 through 2010, China's average annual growth rate of real wages was $13.8 \%$. But the year 2010 alone saw an increase of $22 \%$ of wages. Migrant workers experienced real wage increases of more than $11 \%$ in 2011 . Suddenly higher labor costs drove the injected credit into non industrial sectors, which led to the bubbling of Chinese real properties till now. Increased costs also made China's industrial value-added output growth decelerate to 13.9 percent year-on-year in 2011. Chinese government becomes aware that under the glorious cover of the formidable macro growth of GDP, entrepreneurship lack of indigenous innovation capacity is the weak point of Chinese economy. It is also aware of the importance of domestic demand for China's continuation of investment-driven circulation in the long term, albeit that Chinese internal demand can absorb the new investment for a certain period of time. In fact, the proportion of export added value of industrial firms in total industrial sales reached about $20 \%$ in 2004 . After this peak, it declined to $17 \%$ in 2008 and $12.7 \%$ in 2011. External demand subtracted 0.5 percent from Chinese growth in 2011, compared to a positive contribution of 1 percent in 2010. It continued to contribute negatively in 2012 , subtracting 0.3 percentage points. After many years of export growth, Chinese government also accumulates large amount of foreign currency reserve. Since 2009, new policies, initially under the form of regional industrial restructuring and upgrading packages, have been elaborated to move Chinese firms upward along the global value chain. ${ }^{3}$ With the increasing input in $\mathrm{R} \& \mathrm{D}$ of multinational companies in China, the country's policy now is for reinforcing their positions in the global value chain, mainly concerned of the

3 In the end of 2010, the Chinese central government published its first Mid- to Long-term Industrial Restructuring and Upgrading Plan (2011-2015). According to the plan, China targets an 8-percent growth in value-added output for all industries over the following four years, a 2-percentage-point rise in the value-added ratio from the end of 2010, and a 10 -percent annual increase in overall labor productivity, with the value-added output of emerging industries accounting for 15 percent of the country's total value-added output by 2015 . As for major industrial enterprises, expenditure on research and development will account for at least 1 percent of their revenues. The proportion will rise to at least 3 percent for key industrial enterprises, and they will double the number of patent ownerships over the next four years, according to the plan. Industrial enterprises should enhance their abilities to self-innovate, use advanced technologies to transform traditional businesses, promote energy conservation and eliminate outdated capacity. The enterprises are also encouraged to improve product quality, produce high value-added goods, create local brands, raise competitiveness, and explore overseas markets. Over the next four years, the country will focus on developing the equipment manufacturing industry, optimizing the raw material industry, upgrading the consumer goods industry, improving the competitiveness of the electronics industry, and promoting the development of service industries closely related to industrial production, according to the plan. (Source: Xinhua News Agency of China, 18/01/2012) 
client-led ecosystem. On the other side, policy encourages mainly State-owned firms and mixed firms to jump over the existing global value chain and set up new business directly in foreign markets, often through brown-field investment. Both strategies are aimed to establish direct linkage with foreign customers and users, but both encounter external and internal difficulties.

\subsection{Imitative Entrepreneurs: Barriers to Value Chain Upgrading}

An industrial chain includes activities of product design, raw materials procurement, storage and transportation, order processing, wholesale business, retail distribution, and manufacturing. In contrast to the earlier catching-up of Japan and South Korea, an economy today needs not to develop the whole integrated sector; catching-up firms can instead from the beginning position themselves in the global value chain. From 1990s, most of functions of production and components manufacturing have been moved to China. The globalization of value chain industrialized the whole economy and almost all sectors. This globalization gave an opportunity to whichever Chinese firms, but specifically small and medium sized non-State firms, to absorb and develop production capacity. MNCs organize innovation globally. On average foreign production is less innovation intensive than home production. Comparing with central, they are still periphery. Global standards and position in the world value chains present ways in which firms from emerging economies can overcome the barriers. But they also can constrain the ability of firms based in emerging economies to upgrade their capabilities and appropriate greater value (Goldstein, A., 2008). Chinese firms' position in the global value chain is concentrated in manufacturing. And electronic and technical products manufactured in China contain many components produced in Western countries or Japan, which are then exported to China. It is estimated that $85 \%$ of the components of high-tech products made in China from the United States or Japan. In the case of some sophisticated products, the assembly is done in China but all electronic components are imported. The Chinese added value remains low.

There is additional value to be gained by developing product and entering in marketing activities rather than assembling components. Typically, the value added at the system level is greater than the sum of the value added by the components. But climbing up in global value chain needs firms elaborate clear technological learning strategies and make hard efforts overtime. For exporting relatively low-technology products, learning is a typical routine of Southeast Asian catch-up firms from OEM to ODM to OBM. Learning started from production and component functions, but later some firms extended to engineering, distribution, product design, even marketing and after-sales service. A discrete, stand-alone technology (e.g., the design of a semiconductor chip), especially the technology of production, is more easily transferred than a process competence, which is entwined in the social fabric of a firm, such as marketing capability. Innovation capability is not limited technological; it refers to the capability of combing market opportunities and technological advances. Besides, product innovation and brand management are related to the implicit knowledge (Tidd, J., J. Bessant and K. Pavitt, 2005).

Some Chinese mixed ownership firms originated from institutional entrepreneurship entered into OEM production. These firms also benefited from the boom of domestic market. Often leveraging the technologies that they get from foreign clients to the domestic market, they begin to master all the functions along value chain, from product development to marketing. In domestic markets, their fast growth begins with cost advantages that large scale and broad scope provide. They then continue with heavy investments in manufacturing, marketing, and distribution. These firms, when big enough, will also try to take use of the former reserve of scientific and technological competence, leaked out from former science and technology institutions. They seek support for their technological activities which they know they are not so good in doing OEM. As a result, they are quick climbers in global value chain, since they can leverage their advantages in domestic markets in re-positioning in global value chain. Normally Western firms are also alert on these firms, knowing they can become soon competitors.

But most Chinese firms in global value chain are private firms created by grass roots entrepreneurs in the southern and coastal regions. They are small or medium sized and have no formal access to science and technology resources in China. They don't have resources neither to exploit domestic markets. They are often short of residual profit to re-invest and they spend all the money in introducing production technology and equipment to meet the requirements of foreign clients, who are their sole technology provider and controls their channel to foreign market. Serving as an OEM base for a Western partner is a quick route to increased manufacturing share without the risk. It can yields volume of production and improve process, sometimes even the quality of products. The Western partners' distribution capability allows OEM suppliers to focus all their resources on building product advantage. But for OEMs it is not easy at all to enter markets on their own and convert manufacturing share into brand share. The downstream Western partner would not provide enough information on how to tailor products to foreign markets. So every product design transferred to an OEM partner is more on technical information than on customer preferences and market needs. Chinese OEM firms know only their clients and what clients tell them about the market. No direct access to foreign markets accounts for most of Chinese firms' decisions and their difficulty. Furthermore, these Chinese firms produce for foreign outsourcers often on the second or third tier in the global value chain. They are therefore subordinate to the will of clients and weak for negotiation. To survive in these conditions, firms over-invest in production capacity, ensure cash flow on a daily basis, and suffer from fierce competition 
with other local firms which is imposed by their international buyers. That reduces the cluster effect which is the coordination among small firms in working out innovative ways of business. Their internal technological learning is totally dependent upon the relation with foreign client. Theoretically, developing firms can position them better in global value chain through forming local network or industrial clusters. Nevertheless, the export-oriented clusters in China are characterized by the following aspects: non-exclusivity of contracts; added levels of subcontracting; foreign clients as sole technology source to subcontractors; subcontractors responding to clients but being blind to the market; risk of being eliminated from the value chain once clients cancelling orders, etc. (Arvanitis, R. et W. Zhao, 2012).

Chinese towns and rural areas hosted dynamics where OEM firms get the technology from their clients and sell products abroad. The local governments were always under pressure to keep employment and increase local GDP. So they made efforts to build centers for technical innovation and information, forged links of local firms with universities, arranged for bank loans, organized fairs to promote sales, led OEM producers to seek for markets and more customers, but mainly in Chinese markets, etc. A few years ago there was an initiative of local clustering policy, which had nothing to do with national innovation policy which was biased towards large State-owned firms or foreign company subsidiaries that come with a proprietary technology. The local cluster policy emphasized on organizing local innovation centers to help firms climb up in global value chain. In effect, innovation centers began to create networks of firms, improve innovation capacities, and enhance communication with universities and research centers. In some towns, local government policy promoted innovation centers, especially during difficult economic times, when a need for better quality and higher priced products made sense in China. As such, the innovation centers were mainly oriented toward servicing the local industry, rather than maintaining a competitive edge (Arvanitis, R., Qiu, H., 2009).

The conjuncture of new policies and 2008 crisis interrupted this local policy for clustering. After 2000, the unique financial system of China accumulated so much foreign exchange gained by export of Chinese firms that the Chinese Yuan was under huge pressure to revaluate. China raised its exchange rate and imposed export tax. Chinese government was also anxious of the problem of liquidity surplus in domestic financial market. Four the following four years, it raised interest and tries to tighten credit supply, which increased the financial cost of investment projects in export sector. Raw materials became more expensive than before. Since 2007, Chinese central government also tightened environmental regulations. Wages were rising. In the beginning of 2008, China begun to implement the new Labour Law, which increased enormously the labour cost for firms, though the average wage of a Chinese worker was just $5 \%$ of an American worker, with almost the level of South Korea in 1975. But soon Chinese private entrepreneurs found more challenges coming from domestic policies. In believing that Chinese industry should upgrade quickly in global value chain and carry more technology-intensive activities, Chinese government begun to force the factories in coastal areas (especially in the deltas of Yangzi River and Zhujiang River) to move to interior regions. At the same time, the 2008 economic crisis caused a sharp slowdown in growth of Chinese exports in the year, which drop from $30 \%$ to $7 \%$. For example, according to the Asian Footwear Association statistics, in Guangdong areas, nearly 1,000 shoe factories and related ancillary businesses were terminated or moved to other areas in 2008. Also in the shoe-making province of Zhejiang, according to Wenzhou Footwear Association, a survey of 371 shoe-making firms showed that with 2 months 32 firms were shut down, and 52 stopped their activities.

The 2008-2009 crisis has more impact on the grass roots entrepreneurs than on the institutional entrepreneurs. Many Chinese export private firms quit the global value chain, while the mixed ownership firms such as Haier or Midea had turned to non-industrial sectors, investing heavily in real properties, long before the crisis. Although Chinese labor cost is higher now than before, its firms' manufacturing/export competitiveness is still strong in terms of total costs taking account of transportation, materials, capital reserve and uncertainty in political environment. Therefore, the future of the export industry in China is probably less predictable than most other economies. Employees, employers, Chinese officials are now in a situation that they have never known. They have not yet found their ways to climb higher in the existing value chain and their initial previous seem to be counter balanced by the current domestic policies and crisis.

\subsection{Localized Entrepreneurs: Too Chinese to Be Global}

Compared with small firms forced to climb and quit the global value chains, the big Chinese firms trying to jump directly into advanced foreign markets get much more support from the government (Wang, W. and J.F. Huchet, 2008). But once leaving the specific domestic context, the weak competitiveness of Chinese firms is never so evident. Firm's development in foreign market is in fact an international entrepreneurial process (equivalent to launching a new venture), including exploring and exploiting opportunities, understanding consumers and market dynamics, coming out with innovative business concept and undertaking it with risk across national borders (Mcdougall, P.P. and B. M. Oviatt, 2003). Chinese entrepreneurs are context-specific and good in grasping the opportunities created by the Chinese institutional arrangements. Going abroad makes the institutional opportunity sources of Chinese firms completely irrelevant. They are no longer able to find the opportunities from the institutional background. For example, networking is a powerful tool for entrepreneurship. Although mainland Chinese entrepreneurs are almost all experts in social networking (making the famous Guanxi) within Chinese context, few are competent 
in managing networks with foreigners once they are in a foreign country. Mutual trust, share values, personal contact and respect of other culture are all elements in entrepreneurial networking in a foreign market. Chinese firms often enter in non-compliance with the country's accounting, tax laws, causing dissatisfaction with the local government in turn, which lead to difficulty in obtaining expatriate work visas, etc. The reason why Haier's overseas factories progressively succeeded is its full integration into local network. As Ruimin Zhang, the CEO of Haier said: "Haier's factory in the United States and other countries, are not only to produce and sell products, but also to make Haier's culture, especially Chinese culture and local culture together". Another related factor for entrepreneurial firms competing in international markets is the learning process, often based on technological learning experience in domestic market (Zahra, S.A. Ireland, R.D., and Hitt, M.A., 2000). Learning capability is critical in helping firms overcome their liabilities of foreignness, as much of this liability relates to the foreign firm's lack of local market knowledge. But for entrepreneurship, knowledge about market, technology and competition is often not the most critical asset of the firm to achieve success. The most useful knowledge of entrepreneurship in China is acquaintance with the hierarchy and personal relations with key actors. Private Chinese firms have no habit to learn from foreign markets and customers. Again, the strategies and behavior of Chinese firms in abroad reflect clearly the nature and characteristics of their modes of entrepreneurship within the Chinese context.

Maybe the most significant characteristic of Chinese State-owned firms' internationalization is the role played by the Chinese government. It has played a dominant role through strategic choices that determined the localisation of new activities linked to cooperation with foreign firms. China's "going out" strategy encourages big domestic firms to participate in international capital market and to directly invest overseas. Chinese State is more and more acting as an entrepreneur abroad. Under state oversight, there is an increasing number of State-owned firms carrying out round trip investments, searching for possession and control of assets and resources, especially firms of raw materials. They prefer brown-field investments, since they need real assets and hope to gain access to cutting edge technologies difficult to obtain at home either due to lack of local skills or because of the reluctance of foreign firms to transfer technologies. In the past, these firms expanded only in domestic market, in which they enjoy a well protection of Chinese government. In terms of technological learning, these firms are used to the mode of international transfer from a MNC, negotiated and arranged by the Ministries of government. That is why their overseas acquisitions of technology and knowledge can be simplified as purchasing raw material resources and physical assets. Some of them even move the production facilities back to their Chinese home base after acquisition. Typical examples include BOE's acquisition of Hynix from Hyundai, SAIC's acquisition of SsangYong Motor, Nanjing Auto's purchase of MG Rover, China Chem Bluestar's acquisition of Rhodia Silicon, and SAIC/NAC acquisition of Rover.

Until now, the most successful internationalization cases of Chinese firms are those of non-State firms. Comparing with Indian emerging MNCs, the private Chinese MNCs are very few and very small. Some of them are searching to control raw materials under certain cost level, thus it is rather a strategy of vertical integration than internationalization. Some are searching for expanding production capacity and market share abroad. Some are pushed out of China due to the rising costs of production. Some are developing global brands and expanding their operations abroad, with a view to tapping into foreign pools of knowledge through mergers and acquisitions or green-field investment and the establishment of overseas R\&D. Accessing foreign sources of knowledge has become one of the motives behind outward investment decisions of a still small, but expanding, number of Chinese firms, such as Lenovo, Haier, Huawei, ZTE. Often the internationalization of these firms begins by OEM production for foreign firms/clients, such as Chery's OEM production for Chrysler. Firms then buy similar activities and functions in other countries, such as Wanxiang Group's multiple acquisitions in the North American auto-components sector. The proximity factor played a part: acquisition of necessary skills took place in nearby plants. For example, Haier, trained its international cadres in the Philippines before they were sent further afield. Those engaged in one activity or a given production segment (for example cheap cars) can turn out high volume, master technologies, and profit from economies of scale that help create a competitive advantage for entering other markets, as exemplified by private automakers such as Geely and Chery, who have begun making inroads abroad, especially in Asia and the Middle East.

Their main problem is their mode of entrepreneurship without innovation experience and basis. The non-State Chinese firms emphasize on production facilities and vertical integration to gain competitiveness in price; their focal point is to enlarge market share. But these traditional domestic business models are no more effective in advanced foreign markets, just as the case of TCL's failure integration of Thomson Electronics, except a very few success stories, such as Huawei. In fact innovation is vital to entrepreneurial process in foreign markets, where serving the developed world's more quality-conscious consumers- who are also typically loyal to established brands- requires firms to design and deliver products not comparable to the offerings of developing markets. Doing so requires big changes to the design of products and processes, and changing from low-cost competition strategy to innovation and learning strategy.

\section{Conclusion}

With a second biggest economy in the world, China has produced much less competitive firms than US, Europe, Japan who arrived developed markets 30 years ago with their 
cars and consumer electronics, and even South Korea who arrived 15 years ago with the same categories of products, though the quantity of firms and products "made in China" never stops increasing. If Chinese economy is competitive, its firms and entrepreneurs are not yet. This paradox is due to the specific modes of entrepreneurship in China, which are deeply embedded in its domestic institutions and Keynesian macroeconomic measures.

Institutional structures create opportunities, but also uncertainty. In the Chinese economy where most of financial resources are controlled by the government and most of opportunities are to be found within the multiplicity of institutional arrangements, the focal point in entrepreneurship is directed towards leveraging resources among different firm ownership combinations. Chinese entrepreneurs allocate their resources and creativity to exploit these institutional opportunities, instead of searching innovation and integrating new technology to meet market demand. Once firms have been created, entrepreneurs will establish the specific external linkages around and lead the everyday business in the short-term to seek quick profit.

Thus technology learning becomes only an accessory product in entrepreneurship. Since the launch of economic reform, China has been imitating the Asian model of export-led growth, while benefiting from the presence of foreign firms via FDI as a conduit for acquiring technology and management. In some successful Asian economies, there has been a process of indigenization of technology (e.g., reverse engineering). China imported technology through the entry of foreign capital, leaving the assimilation and control of technology difficult. Entrepreneurship, in Schumpeter's sense, is based on innovation. Some Chinese firms have backed their growth by research and innovation, often with the continued support from government. But most firms grew up without a pertinent inducement for innovation. These characteristics of Chinese entrepreneurship constrain a lot the innovation possibilities of Chinese firms when they try to upgrade in the global value chain or gain direct access to foreign markets. After the 2008 crisis, this Chinese mode of entrepreneurship through constrained learning met its limits.

\section{REFERENCES}

[1] Amsden, Alice (1989), Asia's Next Giant. South Korea and the Late Industrialization, Oxford : Oxford University Press.

[2] Amsden, Alice (2001), The Rise of 'The Rest': Challenges to the West from Late-Industrializing Countries, Oxford University Press, Chapter 1: 1-18.

[3] Goldstein, Andrea (2008), Multinational Companies from Emerging Economies, Palgrave.

[4] Arvanitis R. and Qiu H. (2009), « Research for policy development: Industrial clusters in South China ", in Graham, M. and Woo, J. (Ed.) (2009). Fuelling Economic
Growth. The role of public-private research in development, Ottawa: CRDI/ IDRC, p. 39-85.

[5] Arvanitis, Rigas, Pierre Miège et Wei Zhao (2003), "Regard(s) sur l'émergence d'une économie de marché en Chine." Perspectives chinoises (77), p. 53-65.

[6] Arvanitis, Rigas et Wei Zhao (2012), Les politiques parallèles du développement industriel en Chine, dans China Innovation Inc. Des politiques industrielles aux entreprises innovantes, dir. par Romain Bironneau, Paris : Presses de Sciences Po, pp. 87-116.

[7] Arvanitis, Rigas, Wei Zhao, Haixiong Qiu and Jian-niu Xu (2006), "Technological Learning in Six Firms in South China: Success and Limits of an Industrialization Model." International Journal of Technology Management, 36 (1/2/3), p. $108-125$.

[8] Berger, S. (2006), Made in monde, Paris, Editions du Seuil.

[9] Benoît F. (éd.) (2004), « Croissance et innovation », Cahier français, numéro Décembre, Paris, La Documentation française, $120 \mathrm{p}$.

[10] Boulon, F. (1996), Economie générale, 3eme édition, Paris, Dunod.

[11] Boyer, R. (2009), « Capitalism Strikes Back: Why and What Consequences for Social Sciences? », Revue de la régulation [En ligne], $\mathrm{n}^{\circ} 1 \mid$ Juin 2007, mis en ligne le 24 décembre 2007, Consulté le 07 novembre 2008. URL : http://regulation.revues.org/index2142.html

[12] Dahlman, Carl J. and Jean-Eric Aubert (2001), China and the Knowledge Economy: Seizing the 21st Century, World Bank, 'Overview': 1-17.

[13] Economist (2011), Bamboo Capitalism, March 10th, 2011.

[14] Keynes, J. M. (1936), The General Theory of Employment, Interest and Money, London: Macmillan and Co. Ltd.

[15] Krug, B. (ed.) (2004), China's Rational Entrepreneurs, The development of the new private business sector, London, Routledge Curzon

[16] Krugman, P. (1994), Competitiveness: A Dangerous Obsession, Foreign Affairs, March/April 1994, 28-44.

[17] Lin, Justin Yifu (2012), New structural economics: a framework for rethinking development, Washington D.C.: World Bank.

[18] Lu, Qiwen (1997), Learning and Innovation in Economic Transition: The Rise of Science and Technology Enterprises in Chinese Information Technology Industry, printed paper presented to the International Conference on Knowledge, Economy and Society, Montreal, Canada.

[19] Lundvall, Bengt-Åke (1998), 'Why Study National Systems and National Styles of Innovation?', Technology Analysis \& Strategic Management, 10(4): 407-421.

[20] Mankiw, Gregory N. (2002), Macroeconomics, 5th Edition, Worth Publishers.

[21] Maskell, Peter and Anders Malmberg (1999), 'Localised learning and industrial competitiveness', Cambridge Journal of Economics, 23: 167-185. 
[22] Mcdougall, P.P. and B. M. Oviatt (2003), Some Fundamental Issues in International Entrepreneurship, manuscript submitted to Entrepreneurship Theory \& Practice, $27 \mathrm{pp}$.

[23] Nitsch, Manfred and Frank Diebel (2008), Guānxi Economics: Confucius Meets Lenin, Keynes, and Schumpeter in Contemporary China, Intervention 5 (1), 2008, $77-104$.

[24] Penrose, E. (1995), The Theory of the Growth of the Firm, Oxford University Press.

[25] Redding, Gordon S. and Witt, Michael A. (2007), The Future of Chinese Capitalism: Choices and Chances, Oxford University Press.

[26] Ruffier, Jean, Rigas Arvanitis et Wei Zhao (2007), "Patrons privés et patrons publics au Guangdong: quelques éléments de différentiation des stratégies et des comportements ". Négociation internationale et processus des affaires en Chine. Philippe Béraud, Guy Olivier Faure and Jean-Louis Perrault, (Eds). Paris: Maison Neuve \& Larose, p. 145-156.

[27] Schumpeter, J. (1934), The Theory of Economic Development, Cambridge, Mass: Harvard University Press.

[28] Tanguy, C. et D. Villavicencio (dir.) (2000), « Apprentissage et innovation dans l'entreprise, une approche socio-économique des connaissances ", Technologies/Idéologies/Pratiques, Editions Erès.

[29] Tidd, Joe, John Bessant, and Keith Pavitt (2005), Managing Innovation: integrating technological, market and organisational change, Chichester: John Wiley.

[30] Walder, Andrew (1998), The State as an Ensemble of Economic Actors: Some Inferences from China's Trajectory of Change. Available at http://www.nap.edu/openbook.php?record_id $=5852$ \&page $=4$ 32
[31] Wang Wei and Jean-François Huchet (eds.) (2008), Chinese Firms in the Era of Globalisation, Beijing: China Development Press.

[32] Zahra, S.A. Ireland, R.D., and Hitt, M.A. (2000), International expansion by new venture firms: International diversity, mode of market entry, technological learning and performance. Academy of Management Journal, 43: 925-950.

[33] Zeng, Ming and Peter J. Williamson (2007), Dragons at your door: how Chinese companies are disrupting the rules of global competition, HBS Press.

[34] Zhao, Wei (2000), " Les transferts internationaux de technologie dans l'industrie automobile : une évaluation des efficiences productives contrastées de Peugeot, Honda et Volkswagen en Chine ". Pratique des transferts de technologie et efficience productive dans les pays émergents, Guangzhou (R.P. Chine), 18-22 janvier 2000, INIDET \& IRDGUS

[35] Zhao, Wei (2004), "Understanding China's Economic Growth: A National Innovation System (NIS) Approach". Regional Innovation Systems and Science and Technology Policies in Emerging Economies: Experiences from China and the World, Zhongshan University, UNESCO, Institut de Recherche pour le Développement (IRD), ISESCO, 19-21 April 2004, Guangzhou.

[36] Zhao, Wei (2013), La capacité d'innovation chinoise. Apprentissage technologique dans les industries automobiles et électroniques, PAF Presses académique francophones, Catégorie: Économie, 2013, 540 p.

[37] Zhao, Wei, Arvanitis, R. and La Pira, F. (2011), Innovation policy and local cluster of entrepreneurs in South China, International Journal of Management and Enterprise Development, Vol. 11, Nos. 2/3/4, pp. 109-126. 